\title{
Manufacture of titanium dioxide scaffolds for medical applications
}

\author{
Elaboración de scaffolds de dióxido de titanio para aplicaciones \\ médicas
}

Elaboração de scaffolds de dióxido de titânio para aplicações médicas

Fecha de recepción: 17 de octubre de 2017

Fecha de aprobación: 6 de enero de 2018

\author{
Giovanni Cuervo-Osorio \\ Ana María Jiménez-Valencia*" \\ Cristian Mosquera-Agualimpia** \\ Diana Marcela Escobar-Sierra***
}

\section{Abstract}

The skeletal system is vulnerable to injuries and bone loss over the years, making the use of autologous or allogeneic implants necessary. However, these implants have complications, such as the limited amount of bone to be extracted and the cell death at the extraction site; hence, biomaterials have been developed as platforms for cell growth (scaffolds). Biomaterials and bones have similar properties that facilitate the integration between the material and the bone tissue, helping the tissue to regenerate. Traditional ceramic implants are hydroxyapatite, but given their low mechanical properties, they have been replaced with better inert ceramics. Therefore, this study aims at manufacturing titanium dioxide scaffolds through various techniques, using collagen, polyvinyl alcohol (PVA), sodium chloride, and corn flour as binders to influence pore size. Scaffolds were characterized by a Scanning Electron Microscope (SEM) and evaluated by compression and degradability tests in a Simulated Body Fluid (SBF). The prepared scaffolds had mechanical behaviors with ranges within the bone parameters; among them, the scaffold obtained by infiltration with $10 \%$ PVA presented values of compression strength $(6.75 \mathrm{MPa})$, elastic modulus $(0.23 \mathrm{GPa})$, and porosities (54-67\%) closer to the values of the trabecular bone.

Keywords: compression molding; infiltration; lyophilization; scaffolds.

\section{Resumen}

El Sistema esquelético es vulnerable a lesiones y a perder hueso a lo largo de los años, lo que hace necesario el uso de implantes autólogos o alogénicos; sin embargo, estos implantes tienen complicaciones, como la cantidad limitada de hueso que se extrae y la muerte celular en el sitio de extracción; por lo tanto, se han desarrollado biomateriales como plataformas para el crecimiento celular (scaffolds). Los biomateriales tienen propiedades similares a las del hueso, lo que facilita su integración con el tejido óseo, ayudando a la regeneración de este. Tradicionales los implantes de cerámica son de hidroxiapatitas, pero, debido

\footnotetext{
* Universidad de Antioquia (Medellín-Antioquia, Colombia).

** Universidad de Antioquia (Medellín-Antioquia, Colombia).

*** Universidad de Antioquia (Medellín-Antioquia, Colombia).

****Ph. D. Professor Faculty of Engineering, Universidad de Antioquia (Medellín-Antioquia, Colombia). marcela.escobar@udea.edu.co.
} 
a sus pobres propiedades mecánicas, han sido reemplazados por cerámicas inertes, que tienen mejores propiedades mecánicas. Por lo tanto, el objetivo de este estudio fue fabricar scaffolds de dióxido de titanio, por medio de diferentes técnicas, utilizando colágeno, polivinil alcohol (PVA), cloruro de sodio y harina de maíz como aglutinante para influenciar el tamaño del poro. Los scaffolds se caracterizaron por medio de microscopía electrónica de barrido (SEM) y se evaluaron con pruebas de compresión y degradabilidad en un fluido corporal simulado (SBF). Los scaffolds elaborados presentaron comportamientos mecánicos que están entre el rango normal del hueso; el scaffold obtenido por medio de infiltración, con $10 \%$ de PVA, presentó valores de fuerza de compresión $(6.75 \mathrm{MPa})$, módulos elásticos $(0.23 \mathrm{GPa})$ y porosidad $(54-67 \%)$ cercanos a aquellos reportados para el hueso trabecular.

Palabras clave: infiltración; moldeo por compresión; liofilización; scaffolds.

\section{Resumo}

O Sistema esquelético é vulnerável a lesões e a perder osso ao longo dos anos, o que faz necessário o uso de implantes autólogos ou alogênicos; porém, estes implantes têm complicações, como a quantidade limitada de osso que se extrai e a morte celular no lugar de extração; portanto, têm sido desenvolvidos biomateriais como plataformas para o crescimento celular (scaffolds). Os biomateriais têm propriedades similares às do osso, o que facilita sua integração com o tecido ósseo, ajudando à regeneração do mesmo. Tradicionais os implantes de cerâmica são de hidroxiapatitas, mas, devido a suas pobres propriedades mecânicas, têm sido substituídos por cerâmicas inertes, que têm melhores propriedades mecânicas. Portanto, o objetivo deste estudo foi fabricar scaffolds de dióxido de titânio, por meio de diferentes técnicas, utilizando colágeno, polivinil álcool (PVA), cloreto de sódio e farinha de milho como aglutinante para influenciar o tamanho do poro. Os scaffolds caracterizaram-se por meio de microscopia eletrônica de varredura (SEM) e avaliaram-se com provas de compressão e degradabilidade em um fluído corporal simulado (SBF). Os scaffolds elaborados apresentaram comportamentos mecânicos que estão entre a faixa normal do osso; o scaffold obtido por meio de infiltração, com $10 \%$ de PVA, apresentou valores de força de compressão $(6.75 \mathrm{MPa})$, módulos elásticos $(0.23 \mathrm{GPa})$ e porosidade $(54-67 \%)$ próximos a aqueles reportados para o osso trabecular.

Palavras chave: infiltração; moldagem por compressão; liofilização; scaffolds.

\section{Para citar este artículo:}

G. Cuervo-Osorio, A. M. Jiménez-Valencia, C. Mosquera-Agualimpia, and D. M. Escobar-Sierra, "Manufacture of titanium dioxide scaffolds for medical applications," Revista Facultad de Ingeniería, vol. 27 (48), pp. 17-25, may. 2018. 


\section{INTRODUCTION}

Several bone injuries and defects cause bone loss. Although these defects have been commonly treated with conventional therapies that involve the implantation of autologous, allogeneic or xenogeneic tissue, still complications associated with these implants arise, such as the limited amount of bone to be extracted, the cell death at the extraction site (pain, infection, hematoma, abdominal hernias, etc.), and the potential risks of infectious and immunological diseases (e.g., hepatitis, HIV, prions, etc.). Therefore, it is necessary to explore various alternatives like the use of biomaterials [1] that are bioactive, biocompatible, and that have adequate mechanical properties to withstand the loads to which they will be subjected. Biomaterials that help manufacture hard tissue cell growth platforms, known as scaffolds, provide mechanical resistance to tissues. The scaffolds can be found in different biomaterials, mostly the ceramic type, and can be obtained through different methods such as infiltration, gel-casting, and compaction, among others.

Given that the skeletal system endures heavy loads, the scaffolds that serve as support must provide solid structure, porosity, interconnectivity, and adequate composition, considering that the goal is to develop a structure similar to that generated by collagen cross-linking fibers in the bone [2]. Titanium dioxide is a biomaterial of inert nature, which, due to its ceramic characteristics, provides similar bone properties. This biomaterial has been used to produce scaffolds as an alternative to hydroxyapatite, a biomaterial commonly used that lacks the sufficient mechanical properties for this purpose [3].

In this project, we prepared titanium dioxide scaffolds using infiltration, lyophilization, and compaction, and assessed them mechanically. We used degradability tests and analyzed how the preparation techniques improve the mechanical properties and the porosity of the scaffolds. We established the behavior and degradation time of the samples in Simulated Body Fluid (SBF) and compared the results with those reported in literature for bone.

\section{Methods}

\section{A. Scaffold preparation}

Scaffolds were prepared using three different techniques: infiltration, lyophilization and compaction. For the infiltration technique, we started with a titanium dioxide solution composed of distilled water and $50 \%$ solids, to which sodium polyacrylate was added as a dispersant; the solution was stirred for 10 minutes. Then, with the desired mold size, the polymeric foam was impregnated with the ceramic solution, applying pressure to achieve homogeneous wetting and then dried in an oven for one hour at $120^{\circ} \mathrm{C}$. The same impregnation procedure was repeated. The material was calcined with heating ramps at $450{ }^{\circ} \mathrm{C}$ for one hour, followed by $750{ }^{\circ} \mathrm{C}$ for one hour, and finally the scaffold was sintered at $1200{ }^{\circ} \mathrm{C}$ for two hours.

The scaffolds produced by compaction were prepared with a mixture of titanium dioxide, sodium chloride and corn flour to provide porosity differences. Once the mixtures were made and homogenized, they were compacted using a press with a load of $30 \mathrm{Mpa}$ for two minutes. Subsequently, the formed scaffolds were taken to a muffle to undergo calcination and sintering using the same temperatures used during infiltration. Finally, the scaffolds obtained were subjected to repetitive washes to solubilize the sodium chloride.

To prepare the scaffolds with the lyophilization technique, we started with a titanium dioxide solution composed of distilled water and $50 \%$ solids, to which sodium polyacrylate was added as a dispersant; the solution was stirred for 10 minutes. Afterwards, we added different concentrations of collagen $(10 \%, 15 \%, 20 \%$ and $30 \%)$ and PVA $(10 \%$ and $15 \%$ ) for the different scaffolds. The solutions were subsequently frozen at $-80{ }^{\circ} \mathrm{C}$ and underwent lyophilization for 48 hours.

\section{B. Scaffold characterization}

The morphological characterization of the scaffolds was carried out using a Scanning Electron Microscope (SEM) to describe the shape, pore size, porosity type, and interconnectivity. We used a Scanning Electron Microscope Jeol JSM-6490LV that operates with a $20 \mathrm{KV}$ voltage acceleration and 
is coupled with an EDS brand Oxford Instrument INCA PentaFETx3 for chemical analysis, which allowed to differentiate the elements present in the sample and their proportions. The samples were coated with a layer of gold and observed at different magnifications.

The procedure to determine the scaffolds' porosity followed Liu [4]. Initially, we obtained the net weight of the dry samples and saturated them with distilled water according to the NTC 4321-3 norm, whose protocol instruct immersing the samples in water, removing the excess of water, and weighing them. In addition to measuring the scaffolds' porosity, calculations were made through image analysis using a software coupled to the SEM; this software allowed processing the images on a gray scale and measuring the size of the different pores obtained, which were subsequently averaged. The porosity was also measured by the MOTIC software attached to the stereoscope.

\section{Scaffold evaluation}

The mechanical evaluation was performed through compression tests under the ASTM D882 standard using a Diggimes universal test machine, with a load cell capacity of $4900 \mathrm{~N}$, a loading speed of 5 $\mathrm{mm} / \mathrm{min}$, and a displacement or deformation limit of $75 \%$. The samples had a cylindrical shape with average heights of $22 \mathrm{~mm}$ and average radius of 9 $\mathrm{mm}$.
- The degradation test was performed according to the ASTM F1635-11 standard for weight loss. The dried samples were weighed, immersed in SBF at a neutral $\mathrm{pH}(7.0)$, and incubated at $37^{\circ} \mathrm{C}$ for 28 days. Testing was executed three times. Once the incubation period ended, the samples were removed from the solution and dried to proceed with the weighing. In addition, the $\mathrm{pH}$ of the SBF solution was measured to determine whether degradation had any effect on this value.

\section{Results}

In general terms, the morphology of the resulting scaffolds was similar (Fig. 1), however, they differed in their shape due to the type of mold used. The scaffolds obtained by infiltration with polymeric foam (Figs. 1a, 1b) maintained the structure copied from the polyurethane foam, with differences in porosity since the pores can be clogged before the impregnation sequences. The scaffolds obtained by compacting with different percentages of $\mathrm{NaCl}$ (Figs. 1c-1e) had no significant morphological differences when examined with the naked eye, but a strong structure was detected even after the washing was completed to dissolve the salt, maintaining dimensional stability. The scaffolds compacted with organic material (Figs. 1d-1g) retained the block shape after sintering, however, the structural stability achieved was not as good as with the salt, falling apart when manipulated.

Scaffold obtained by infiltration

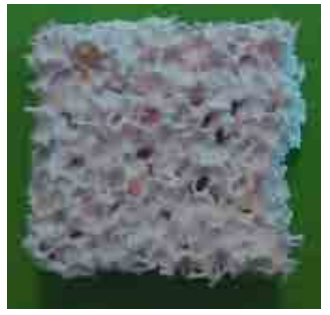

a) with one layer

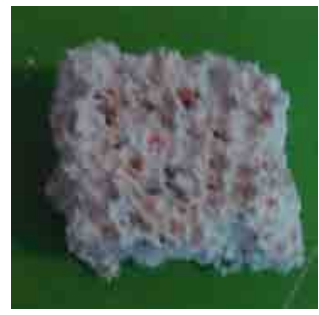

b) with two layers

Scaffolds obtained by compaction with $\mathrm{NaCl}$ and Organic Material (OM) 


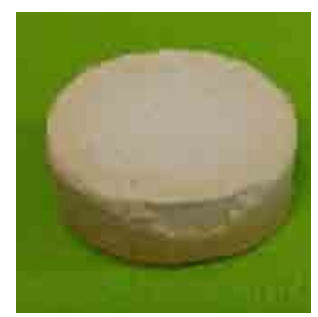

c) $30 \% \mathrm{NaCl}$

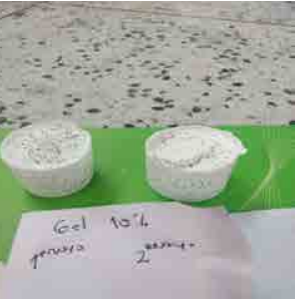

h) $10 \% \mathrm{Col}$

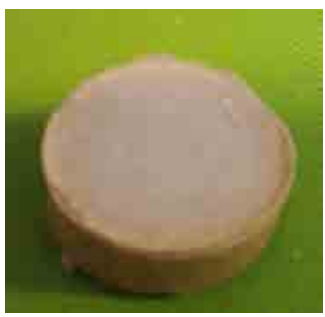

d) $40 \% \mathrm{NaCl}$

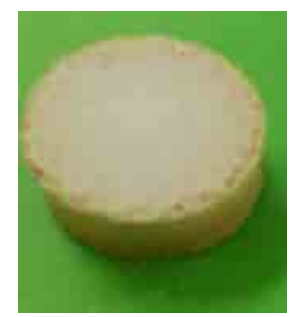

e) $50 \% \mathrm{NaCl}$

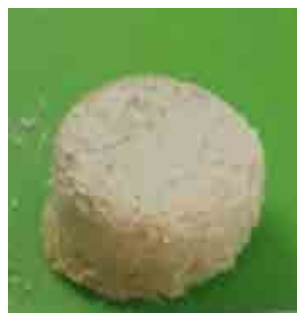

f) $40 \% \mathrm{OM}$

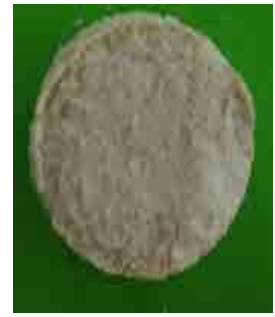

g) $50 \% \mathrm{OM}$

Scaffolds obtained by lyophilization with Collagen (Col) and PVA

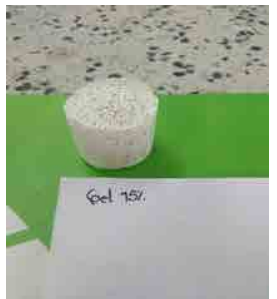

i) $15 \% \mathrm{Col}$

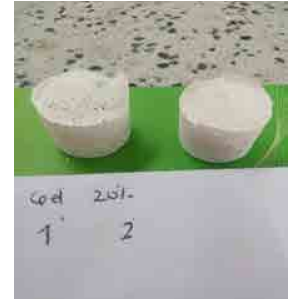

j) $20 \% \mathrm{Col}$

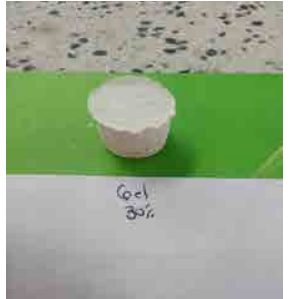

k) $30 \% \mathrm{Col}$

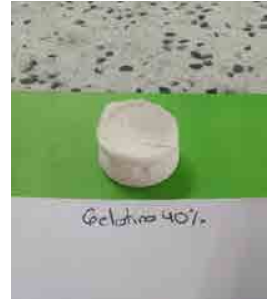

1) $40 \% \mathrm{Col}$

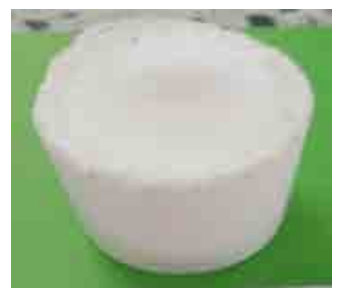

m) $10 \% \mathrm{PVA}$

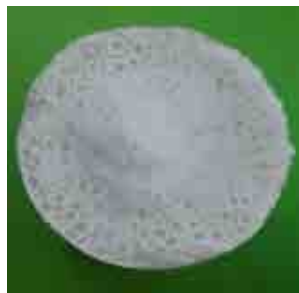

n) $15 \% \mathrm{PVA}$

Fig. 1. Morphology of the scaffolds obtained by infiltration (a-b), compaction (c-g), and lyophilization (h-n).

As the percentage of collagen increased, the obtained scaffolds became more compact with a more continuous matrix, achieving a better pore distribution and homogeneous pore size. The consistency to touch was much more stable and retained the shape and dimensions longer when dry; moreover, a higher percentage of PVA increased porosity without affecting the structure after lyophilization.

\section{A. Mechanical evaluation of the scaffolds}

The mechanical properties obtained showed that for the infiltrated samples, the number of layers and sinters influenced the mechanical resistance, being the compressive strength greater for the sample with one layer $(13.3 \mathrm{MPa})$ than for the sample with two (4.6 MPa) (Table 1). This may occur due to the impregnation process of intermediate drying, where the particles do not adhere easily and, when sintered later, acquire a lower capacity to resist mechanical stress due to the formation of an interface, making the scaffold a sample with low particle adhesion $[5,6]$. In contrast, the samples compacted with $\mathrm{NaCl}$ increased in compression resistance slightly when the percentage of $\mathrm{NaCl}$ increased from $30 \%$ to $40 \%$ but decreased again when $\mathrm{NaCl}$ increased to $50 \%$ (Table I). Scaffolds so compact displayed an unstable behavior to calculate the mechanical properties, perhaps because solubilization was inadequate, leaving salt crystals inside the sintered blocks. The samples compacted with organic material showed that increasing the percentage of organic material decreases the mechanical properties; this phenomenon occurs when the organic material degrades during sintering of the scaffold and generates a greater porosity within the material, as reported by Saiz [7]. 


\begin{tabular}{|c|c|c|c|}
\hline \multicolumn{4}{|c|}{$\begin{array}{c}\text { TABLE I } \\
\text { COMPRESSIVE STRENGTH AND YOUNG's MODULUS FOR THE SCAFFOLDS OBTAINED }\end{array}$} \\
\hline TECHNIQUE & MATERIAL & $\begin{array}{l}\text { COMPRESSIVE } \\
\text { STRENGTH (MPa) }\end{array}$ & $\begin{array}{c}\text { YOUNG'S } \\
\text { MODULUS (GPa) }\end{array}$ \\
\hline \multirow{2}{*}{ Infiltration } & $\mathrm{TiO}_{2} 1$ layer & 13.30 & 3.15 \\
\hline & $\mathrm{TiO}_{2} 2$ layers & 4.60 & --- \\
\hline \multirow{5}{*}{ Compaction } & $\mathrm{TiO}_{2}+\mathrm{NaCl} 30 \%$ & 16.00 & 13.8 \\
\hline & $\mathrm{TiO}_{2}+\mathrm{NaCl} 40 \%$ & 22.59 & --- \\
\hline & $\mathrm{TiO}_{2}+\mathrm{NaCl} 50 \%$ & 6.5 & --- \\
\hline & $\mathrm{TiO}_{2}+$ organic material $40 \%$ & 21.97 & 6.2 \\
\hline & $\mathrm{TiO}_{2}+$ organic material $50 \%$ & 15.76 & 5.2 \\
\hline \multirow{6}{*}{ Lyophilization } & $\mathrm{TiO}_{2}+$ collagen $10 \%$ & 5.16 & 1.05 \\
\hline & $\mathrm{TiO}_{2}+$ collagen $15 \%$ & 6.0 & 1.09 \\
\hline & $\mathrm{TiO}_{2}+$ collagen $20 \%$ & 17.00 & --- \\
\hline & $\mathrm{TiO}_{2}+$ collagen $30 \%$ & 13.22 & --- \\
\hline & $\mathrm{TiO}_{2}+$ PVA $10 \%$ & 6.75 & 0.23 \\
\hline & $\mathrm{TiO}_{2}+$ PVA $15 \%$ & 4.60 & 0.75 \\
\hline
\end{tabular}

The lyophilized samples with collagen showed a direct relationship between the percentage of collagen and the mechanical strength of the material: the lower the percentage of collagen, the lower the mechanical strength (Table 1); the higher the collagen percentage, the fewer defects in the internal structure of the material [8], which increases the scaffolds compressive strength without fracturing. Moreover, the samples lyophilized with PVA showed that increasing PVA percentage decreases the compressive strength, which suggests that the nature of the polymer binder influences the mechanical behavior strongly (Table I).

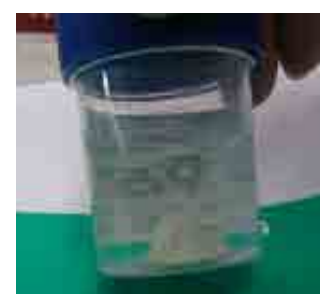

a) Infiltrated

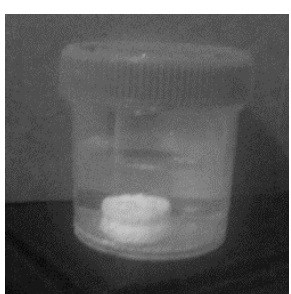

b) Compacted $\mathrm{NaCl}$

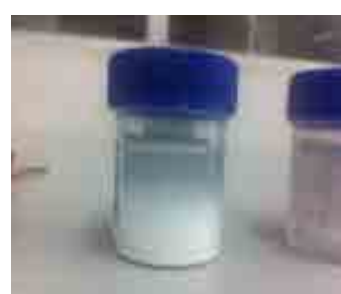

c) Compacted OM

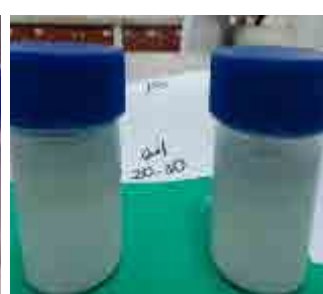

d) Lyophilized $20 \%$ and $30 \% \mathrm{Col}$

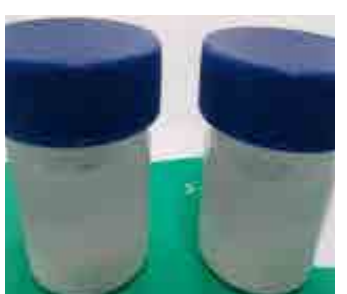

e) Lyophilized $10 \%$ and $15 \%$ PVA

FIG. 2. Degradation test for the different scaffolds.

After 28 days, the scaffolds obtained by infiltration and by compaction with $\mathrm{NaCl}$ did not degrade (Figs. 2a and 2b), whereas the rest of the scaffolds deteriorated considering that the weight of the dried sample changed substantially from the initial one. Noticeably, the samples obtained by lyophilization failed before 24 hours, probably because of the presence of PVA and collagen, which dissolve with an increase in temperature, while the scaffolds obtained by infiltration showed a better structure. Additionally, the scaffolds obtained by lyophilization with collagen absorbed water considerably, increasing their volume with regards to the initial calculation; while those with PVA tended to deform, losing their original shape, and becoming a viscous paste, therefore, the porosity calculations yielded unreliable results. 


\section{TABLE II}

POROSITY PERCENTAGE OF THE DIFFERENT SCAFFOLDS

\begin{tabular}{llc}
\hline \multicolumn{1}{c}{ TECHNIQUE } & MATERIAL & POROSITY (\%) \\
\hline \multirow{2}{*}{ Infiltration } & $\mathrm{TiO}_{2} 1$ layer & 66.97 \\
& $\mathrm{TiO}_{2} 2$ layers & 58.96 \\
\hline \multirow{2}{*}{ Compaction } & $\mathrm{TiO}_{2}+$ sodium chloride & 18.6 \\
& $\mathrm{TiO}_{2}+$ organic material & 57.8 \\
\hline \multirow{3}{*}{ Lyophilization } & $\mathrm{TiO}_{2}+30 \%$ collagen & 54.53 \\
& $\mathrm{TiO}_{2}+10 \%$ PVA & 52.61 \\
& $\mathrm{TiO}_{2}+15 \%$ PVA & 57.14 \\
\hline
\end{tabular}

The results show that the porosity of the manufactured scaffolds varied between $52 \%$ and $67 \%$ (Table II); this range is within that reported in the literature for trabecular bone (30-90\%) [9, 10]. However, the porosities found using the three techniques differed. For example, the scaffolds infiltrated with two layers showed lower porosity because the ceramic solution sealed the pores once they were formed. Likewise, the porosity of the samples obtained by compaction depended on the binder material used; for instance, the sodium chloride, although soluble, crystallized at high temperatures, affecting the speed of solubilization, and given the short washing time, the porosity was lower than with the organic material, which seems to have evaporated almost completely with the sintering temperature. Finally, the porosities in the lyophilized scaffolds with different percentages of collagen and PVA were directly proportional to the amount of agent used: the more collagen and PVA used, the greater the percentage of porosity; this occurs because the amount of solid solvent to sublimate during lyophilization affects the pore morphology differently (Fig. 3).

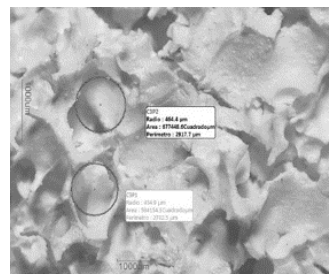

a) Infiltrated

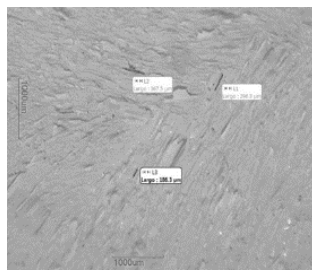

b) Compacted $30 \%$ $\mathrm{NaCl}$

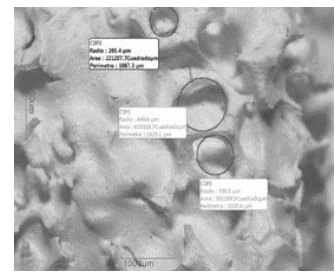

c) Compacted $50 \% \mathrm{OM}$

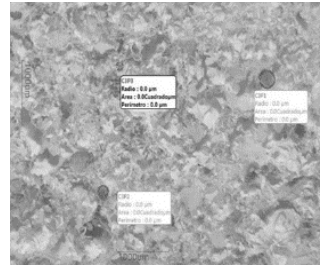

d) Lyophilized 30\% Col

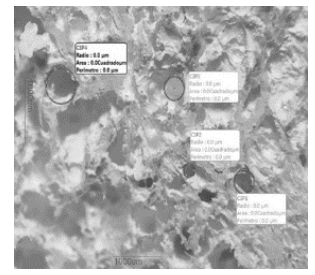

e) Lyophilized 15\%

PVA

Fig. 3. $\mathrm{TiO}_{2}$ scaffolds prepared by different techniques observed at stereoscope $(1000 \mathrm{X})$.

The microscopies reveal structures with superficial porosities (Fig. 3). The scaffolds obtained by infiltration (Fig. 3a) retained the polymeric foam structure and had a homogenous pore distribution all around the surface, which would guarantee good cell adhesion. Additionally, the scaffolds obtained by compaction, both for $30 \% \mathrm{NaCl}$ and $50 \%$ organic material, had very compact structures with closed porosities (Figs. 3b, 3c), although the sample compacted with organic material had a little more porosity. The lyophilized scaffolds had useful porosities for medical applications. 


\section{TABLE III}

AVERAGE PORE SIZE OF THE PREPARED SCAFFOLDS

\begin{tabular}{llc}
\hline \multicolumn{1}{c}{ TECHNIQUE } & MATERIAL & PORE SIZE $(\mu \mathrm{m})$ \\
\hline \multirow{2}{*}{ Infiltration } & $\mathrm{TiO}_{2} 1$ layer & 2207.6 \\
& $\mathrm{TiO}_{2} 2$ layers & --- \\
\hline \multirow{2}{*}{ Compaction } & $\mathrm{TiO}_{2}+$ sodium chloride & --- \\
& $\mathrm{TiO}_{2}+$ organic material & 2825.1 \\
\hline \multirow{2}{*}{ Lyophilization } & $\mathrm{TiO}_{2}+30 \%$ collagen & 617.5 \\
& $\mathrm{TiO}_{2}+10 \%$ PVA & 592.3 \\
\hline
\end{tabular}

As reported in the literature, for an adequate cellular adhesion to take place, the pore size should be between $5 \mu \mathrm{m}$ and $500 \mu \mathrm{m}$ [3]. Comparing these data with the sizes observed with the stereoscope, the scaffold that approximates the most is the one obtained by lyophilization with PVA, with an average pore size of $592.3 \mu \mathrm{m}$ (Table III), a $18 \%$ deviation with respect to the maximum value reported in the literature.

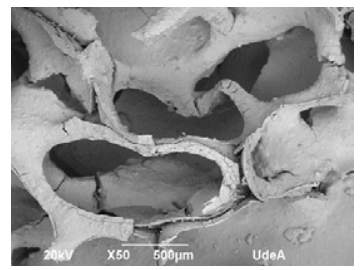

a) Infiltrated

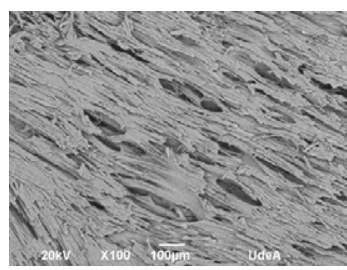

b) Compacted $30 \%$ $\mathrm{NaCl}$

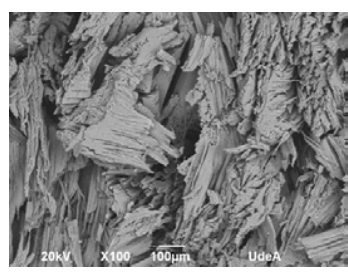

c) Compacted $50 \% \mathrm{OM}$

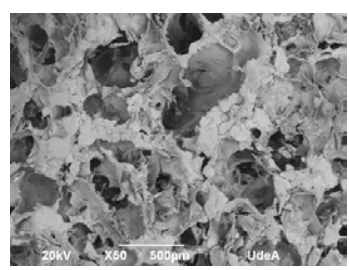

d) Lyophilized 30\% Col

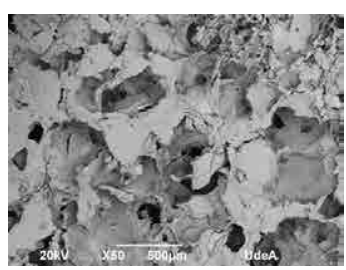

e) Lyophilized $15 \% \mathrm{Col}$

Fig. 4. Microscopy images of the scaffolds obtained using different techniques.

The morphological differences between all the samples were verified with the microscopy images. The porosity inside the samples compacted with $\mathrm{NaCl}$ was lower, corroborating the crystallinity of the salt and the non-solubility during the final washings (Fig. 4b); whereas the opposite was observed in the samples compacted with organic material, which apparently evaporated with the sintering temperature. The samples lyophilized with collagen (Fig. 4d) and PVA (Fig. 4e), as well as the samples obtained by infiltration, had higher porosities and even pore inter-connectivity between them.

\section{Conclusions}

The different binders used to carry out the lyophilization technique caused an elastic behavior in the samples, obtaining acceptable values for Young's Modulus. Furthermore, the porogenic agents (e.g., sodium) used in the compaction technique were adequate, but they require rigorous washing to guarantee the solubility of the salts and the achievement of the appropriate pore size. Finally, the scaffolds obtained through lyophilization using $10 \%$ PVA had a more similar pore size to that of the bone, along with similar mechanical properties; this makes this technique one of the most promising in manufacturing scaffolds useful for bone tissue engineering.

\section{REFERENCES}

[1] A. L. Pérez, V. V. Ortega, L. Meseguer, M. A. Baños, P. Sepúlveda, and M. C. Sanz, "Implante óseo de la espuma de hidroxiapatita. Estudio experimental en conejos," Rev Esp. Patol., vol. 38 (2), pp. 14-20, Jan. 2005.

[2] J. Park, and R. Lakes, Biomaterials: An Introduction. 3ra. ed. USA: Springer, 2007. 
[3] J. I. González, D. M. Escobar, and C. P. Ossa, "Influence of the Type of Manufacturing Technique on the Porosity and Interconnectivity of Hydroxyapatite Scaffolds," Int. J. of Mat. Eng. Innovation, vol. 7 (2), pp. 104-114, Dec. 2016. DOI: https://doi.org/10.1504/IJMATEI.2016.079554.

[4] J. Liu, and X. Miao, "Porous alumina ceramics prepared by slurry infiltration of expanded polystyrene beads," J. of Mat Sc., vol. 40 (23), pp. 6145-6150, Dec. 2005. DOI: https://doi.org/10.1007/ s10853-005-3165-3.

[5] T. Yang, J. M. Lee, S. Y. Yoon, and H. C. Park, "Hydroxyapatite scaffolds processed using a TBAbased freeze-gel casting/polymer sponge technique," J. Mater Sci. Mater. Med., vol. 21 (5), pp. 1495-1502, May. 2010. DOI: https://doi.org/10.1007/s10856010-4000-1.

[6] H. R. Ramay, and M. Zhang, "Preparation of porous hydroxyapatite scaffolds by combination of the gelcasting and polymer sponge methods," Biomaterials, vol. 24 (19), pp. 3293-3302, Aug. 2003. DOI: https:// doi.org/10.1016/S0142-9612(03)00171-6.

[7] E. Saiz, L. Gremillard, G. Menéndez, K. Miranda, P. Gryn, and A. P. Tomsia, "Preparation of porous hydroxyapatite scaffolds," Mat. Sc. and Eng: C, vol. 27 (3), pp. 546-555, Apr. 2007. DOI: https://doi. org/10.1016/j.msec.2006.05.038.

[8] S. Deville, E. Saiz, and A. P. Tomsia, "Freeze casting of hydroxyapatite scaffolds for bone tissue engineering," Biomaterials, vol. 27 (32), pp. 54805489. Nov. 2006. DOI: https://doi.org/10.1016/j. biomaterials.2006.06.028.

[9] J. I. González, D. M Escobar, and C. P. Ossa, "Métodos de fabricación de cuerpos porosos de hidroxiapatita, revisión del estado del arte," Rev. ION, vol. 27 (2), pp. 55-70. Dec. 2014.

[10] J. I. González, D. M. Escobar, and C. P. Ossa, "Porous bodies of hydroxyapatite produced by a combination of the gel-casting and polymer sponge methods," $J$. of Adv Res, vol. 7 (2), pp. 297-304, Mar. 2016. DOI: https://doi.org/10.1016/j.jare.2015.06.006. 
